\title{
Dermal fibroma in olive barb Systomus sarana (Hamilton, 1822): a case study
}

\author{
M. K. SAHOO, P. RAJESH KUMAR, S. PATTANAYAK, P. C. DAS AND P. K. SAHOO \\ ICAR-Central Institute of Freshwater Aquaculture, Kausalyaganga, Bhubaneswar - 751 002, Odisha, India \\ e-mail:pksahoo1@hotmail.com
}

\begin{abstract}
Systomus sarana (Hamilton, 1822) (weight; $370 \mathrm{~g}$; length: $29.0 \mathrm{~cm}$ ) obtained from a carp polyculture pond revealed presence of a solid nodular tumorous mass on right dorso-lateral side of the body. Surgical excision and further histopathological examination of the focal non-invasive mass revealed that the tumor is a fibroma covered by thick stratified squamous epithelium. The fibroma had a compact fibrous stroma organised in whorls and bundles.
\end{abstract}

Keywords: Fibroma, Olive barb, Systomus sarana

Majority of skin tumors in fish are not associated with mortality or even serious damage to affected fishes. Nomenclature of skin tumors are generally based on the origin of proliferative cells revealed by histology and degree of malignancy (Budd and Roberts, 1978). The most common forms of mesenchymal tumors are of fibrous connective tissue origin. Bundles of fibrous tissue form a tag to attach the fibroma to body mass. These may present as elevated mass on any part of the body tissue. The surface of fibroma is mostly pigmented and devoid of scales. Upon dissecting, it shows whitish to pale pink homogenous hard mass of tissue. The cells show rare mitotic figures and are long, spindle-shaped in nature with less cytoplasmic mass. Further, the cells are densely stained and well separated by thick collagen fibres (Roberts, 2012).

There are multifactorial reasons behind tumor development in fish. Mechanical damage of the skin causing constant irritation or parasitic encystment may cause tumor development, mostly hyperplastic epidermis (Anders and Yoshimizu, 1994). Most skin tumors in fish are caused by viruses (Coffe et al., 2013). The causative agents of most commonly seen fibromas in farmed or wild fish are not properly studied, though environmental pollution and infectious agents might play important role. Walker (1969) and Yamamoto et al. (1976) described dermal fibrosarcoma incidences of up to $5 \%$ in mature American pike-perch. Wellings (1965) attempted a preliminary review on fibroma and its variants. Similarly, a case of fibroma in Labeo rohita juvenile has been reported earlier (Pillai and Thampy, 1990). However, there is scarce report on incidence of tumors in the olive barb Systomus sarana (Hamilton, 1822). The present paper appears to be the first description on occurrence of tumor in S. sarana, that forms a component in carp polyculture systems in India, with high economic value.

S. sarana (weight: $370 \mathrm{~g}$; length: $9 \mathrm{~cm}$ with the tumorous mass was obtained during routine sampling from a carp polyculture pond in the farm of the ICAR-Central Institute of Freshwater Aquaculture (ICAR-CIFA), Kausalyaganga, Bhubaneswar, India. The affected fish was collected from a pond dedicated for rearing of broodstock of minor carps and barbs. The pond was stocked with Puntius gonionotus, S. sarana, Labeo fimbriatus and Labeo gonius advance fingerlings (20-40 g) at equal species ratio and at combined density of 4000 nos. ha- $\mathrm{ha}^{-1}$ to raise broodstock. Water quality parameters in the pond were measured at fortnightly intervals and suitable growing conditions were maintained with periodic liming and fertilisation measures as per standard culture protocols. The affected fish was collected from the broodstock pond during sampling in the $11^{\text {th }}$ month of stocking. The fish was anaesthetised with MS222 and the solid nodular tumorous mass on the right dorso-lateral side of the body (Fig. 1) was excised. The collected tumor sample was preserved in $10 \%$ neutral buffered formalin. The tissue was processed for histopathological analyses, embedded in paraffin wax, sectioned and stained with routine haematoxylin and eosin as well as Van Gieson's stain for collagen (Culling et al., 1985). The stained sections were analysed under trinocular compound microscope and photomicrographed.

Dissection of the tumor revealed non-vascular whitish growth on the muscle tissue, attached to body with hard 


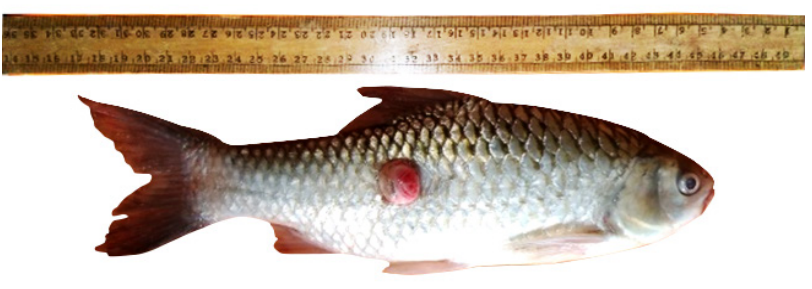

Fig. 1. S. sarana with tumour like outgrowth on the dorso-lateral side

mass without deep penetration (Fig. 2). Microscopically, the tumor appeared as a tissue layered with normal epidermis and layer of dermis which contained engorged blood vessels with mild inflammatory reaction (Fig. 3). The inner mass of the tumor comprised poorly vascularised nodule with very dense coarse bundle of fibrous tissue arranged in whorls and streams and was found paucicellular in nature (Fig. 4). The cells were found spindle shaped with round to ovoid nuclei with sparse mitotic nuclei. The fibrous stroma comprised collagenous tissue bundles (Fig. 5). Pronounced perivascular infiltration of mononuclear cells was mostly seen (Fig. 6).

Predisposing factors such as mechanical injury, carcinogens, viruses, parasites, irritants and pollution have been reported to be responsible for tumor induction in teleosts (Lopez and Raibaut, 1981; Stoskopf, 1993; Constantino et al., 1999). The inflammatory response

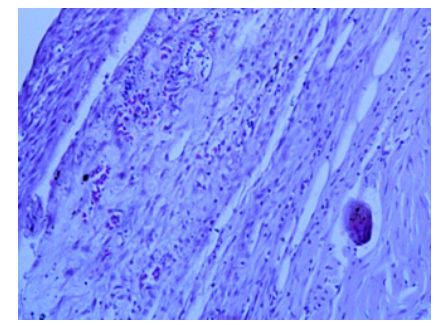

Fig. 3. Dermis from the fibroma showing engorged blood vessels and mild inflammatory reaction (H\& E; X 200)

\section{Acknowledgements}

The authors are thankful to the Director, ICAR-CIFA, Bhubaneswar for providing facilities during this study. Funding support through the National Surveillance Programme for Aquatic Animal Diseases project is duly acknowledged.

\section{References}

Anders, K. and Yoshimizu, M. 1994. Role of viruses in the induction of skin tumours and tumours-like proliferations of fish. Dis. Aquat. Org., 19: 215-232.

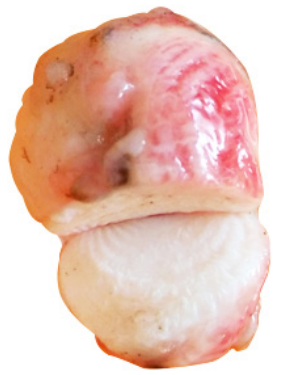

Fig. 2. Excised tumor showing non-vascular whitish firm homogenous mass

noticed in this tumor on the superficial layer could be attributed to either mechanical injury to the tumor surface followed by secondary bacterial infection or induction of tumor due to virus, though viral inclusions were not observed on histological examination. Similarly, inflammatory reactions were also noticed in fibromas described in mullet (Lopez and Raibaut, 1981) and goldfish (Constantino et al., 1999). Harshbarger (1972) described presence of inflammatory reaction in $25 \%$ of fibromas. Inflammatory responses due to viral etiology in tumors have been described by Duncan (1978); Manier et al. (1984) and Francis et al. (1993). Hence, further investigations employing electron microscopy, molecular and cell culture studies would be of help to establish probable viral etiology in this case.

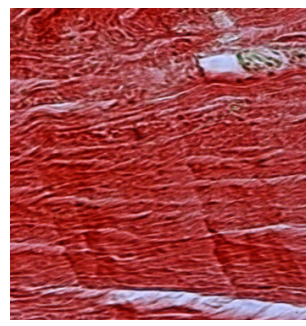

Fig. 5. Fibroma stained with Van Gieson's stain for collagen tissue (H \& E; X 200).

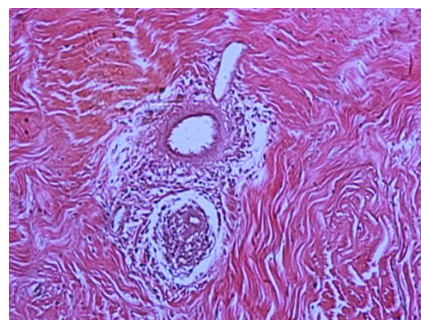

Fig. 6. Perivascular mononuclear infiltration in the fibroma (H \& E; X 200)
Budd, J. and Roberts, R. J. 1978. Neoplasia of teleosts. In: Roberts, R. J. (Ed.), Fish pathology. Bailliere Tindall, London, p. 105-113.

Coffee, L. L., Casey, J. W. and Bowser, P. R. 2013. Pathology of tumours in fish associated with retroviruses: a review. Vet. Pathol., 50: 390-403.

Constantino, F., de Ocampo, A. A. and Garcia-Marquez, L. J. 1999. Dermal fibroma in goldfish, Carssius auratus (L.). J. Fish Dis., 22: 223-226. 
Culling, C. F. A., Allison, R. T. and Ban, W. T. 1985. Cellular pathology technique, $4^{\text {th }}$ edn. Butterworth \& Co. Ltd., London, 168 pp.

Duncan, I. B. 1978. Evidence for an oncovirus in swimbladder fibrosacroma of Atlantic salmon, Salmo salar L. J. Fish Dis., 1: 127-131.

Francis, F. R., Bolon, B., Fraser, W. and Reed, P. 1993. Lip fibroma associated with retrovirus-like particles in angel fish. J. Am. Vet. Med. Ass., 202: 427-429.

Harshbarger, J. C. 1972. Work of the register of tumors in lowest animals with emphasis on fish neoplasms. In: Mawdesley Thomas, L. (Ed.), Diseases of fish, Proceedings of the $30^{\text {th }}$ Symposium of the Zoological Society of London, Zoological Society of London, Academic Press, London, p. 285-303.

Lopez, A. and Raibaut, A. 1981. Multiple cutaneous fibromas in a mullet, Mugil cephalus L. J. Fish Dis., 4: 169-174.
Manier, J. F., Raibaut, A., Lopez, A. and Rioux, J. A. 1984. A calcified fibroma in the common carp, Cyprinus carpio $\mathrm{L}$. J. Fish Dis., 7: 283-292.

Pillai, C. T. and Thampy, D. M. 1990. Occurrence of fibroma in a major carp, Labeo rohita. Indian J. Fish., 37: 77-78.

Roberts, R. J. 2012. Neoplasia of teleosts. In: Fish pathology, $4^{\text {th }}$ edn., Baillere-Tindall, London, p.177-185

Stoskopf, M. K. 1993. Fish medicine. W. B. Saunders, Mexico City, Mexico.

Walker, R. 1969. Virus associated with epidermal hyperplasia in fish. Nat. Cancer Inst. Monog., 31: 195-207.

Wellings, S. R. 1965. Neoplasia and primitive vertebrate phylogeny: echinoderms, prevertebrates and fishes: A review. Nat. Cancer Inst. Monog., 31: 59-128.

Yamamoto, T., MacDonald, R. D., Gillespie, D. C. and Kelly, R. K. 1976. Viruses associated with lymphocystis disease and dermal sarcoma of walleye (Stizo tedion vitreum vitreum). J. Fish. Res. Board Canada, 3: $2408-2419$.

Date of Receipt : : 07.09.2016

Date of Acceptance : 12.02 .2017 